\title{
Enduring Lessons and Opportunities Lost from the San Fernando Earthquake of February 9, 1971
}

Paul C. Jennings, M.EERI

Twenty-five years have passed since the San Fernando earthquake of February 9, 1971. The paper reviews the lessons learned and not learned from this notable event. Most of the major lessons were reported within a few weeks of the earthquake by a panel appointed by the National Academies of Sciences and of Engineering. In this paper, the status of each of the eighteen general lessons cited by the panel is reviewed, plus two additional lessons selected from other studies of the earthquake. The lessons learned ranged broadly and concerned measures needed to reduce future earthquake hazards, as well as recommended scientific and engineering efforts. Although all of the lessons learned were not heeded, the San Fernando earthquake represented a turning point in public awareness and in actions taken to reduce earthquake hazard. Recent earthquakes have shown, however, that much remains to be done.

\section{INTRODUCTION}

The San Fernando earthquake occurred almost exactly 25 years ago on February 9 , 1971 , at 6 o'clock in the morning. Everyone who was in the area remembers what happened then and can recall details of how they responded to the strong shaking of this magnitude 6.6 (later 6.4) event. The earthquake took 64 lives and caused damage in the range of $\$ 500$ million to $\$ 1$ billion dollars, primarily in the northern San Fernando valley. The dollar loss converts to about $\$ 2$ to $\$ 4$ billion dollars in today's figures. The damage was thought to be severe at the time, but the Northridge earthquake with $\$ 20$ to $\$ 30$ billion in damage and the Kobe earthquake, with an estimated $\$ 100$ billion in damage, showed later that much more extensive damage could occur.

For months and years afterward all the "earthquake professionals" were deeply involved in the aftermath of the San Fernando earthquake: performing studies, writing reports, preparing plans, going to meetings--even participating in talk shows.

We learned many "lessons" from the earthquake and drew many conclusions. As always

California Institute of Technology, Pasadena, CA 91125 
seems to be the case, many of these lessons were repeats of lessons that had been ignored or only partly heeded in previous earthquakes. Which of the lessons learned or relearned in San Fernando have endured, and which have faded to lost opportunities or lessons to be learned again in the Whittier, Coalinga, Sierra Madre, Loma Prieta, Landers, Northridge, and Kobe earthquakes--that is the subject of this paper, which is adapted from an address given at the EERI annual meeting in Los Angeles, California on February 8, 1996.

When one says a lesson has been learned or has endured, it is important to say by whom. A narrow approach is to specify that the "whom" is the related professional communities: the engineers, scientists, social scientists, and government officials who study or deal with earthquakes and earthquake risk. This group of professionals learns rather quickly and they tend not to forget the lessons of San Fernando or other lessons of the past. A broader definition of "whom", and the one I am using herein, is the general public, the body politic, and a lesson is not considered learned or has not endured unless specific actions have occurred that prove that to be so.

\section{THE NAS/NAE/NRC REPORT}

A primary source for looking at the lessons of the San Fernando earthquake is a small but remarkable report written by a group of highly qualified people and published within just a few weeks of the earthquake.

The San Fernando Earthquake of February 9, 1971--Lessons From a Moderate Earthquake on the Fringe of a Densely Populated Region (National Academy of Sciences, National Academy of Engineering, 1971).

The panelists were Clarence Allen, Bruce Bolt, Anton Hales, Robert Hamilton, John Handin, George Housner, Don Hudson, Carl Kisslinger, Jack Oliver, and Karl Steinbrugge. The staff members were Joe Berg and Albert Bove. The panel met on February 25-26, 1971, and the report was transmitted to the President of the United States on March 22, 1971, only four weeks later.

This group of very knowledgeable engineers and scientists pointed out 18 lessons. I want to go through them and make observations on whether the lesson has endured, has been ignored, or perhaps superseded by what we have learned since then.

As most readers will know, many reports of the San Fernando earthquake came out later, mostly devoted to specific aspects of the earthquake or its effects. Where general conclusions were made, they tended to reinforce or elaborate on the basic lessons put forward by the NAS/NAE/NRC panel. I have re-examined several of these reports and will address one or two selected lessons from them, but first I want to look at the lessons from the NAS/NAE/NRC report.

The lessons are addressed in the same order as they appeared in the report. 


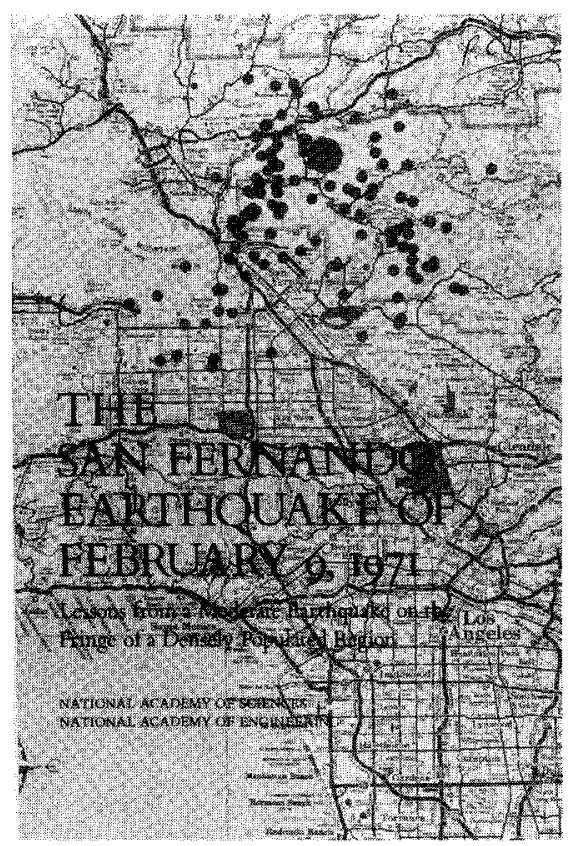

Figure 1. Cover of the brief report published by the National Academy of Sciences and the National Academy of Engineering presenting lessons learned from the San Fernando earthquake.

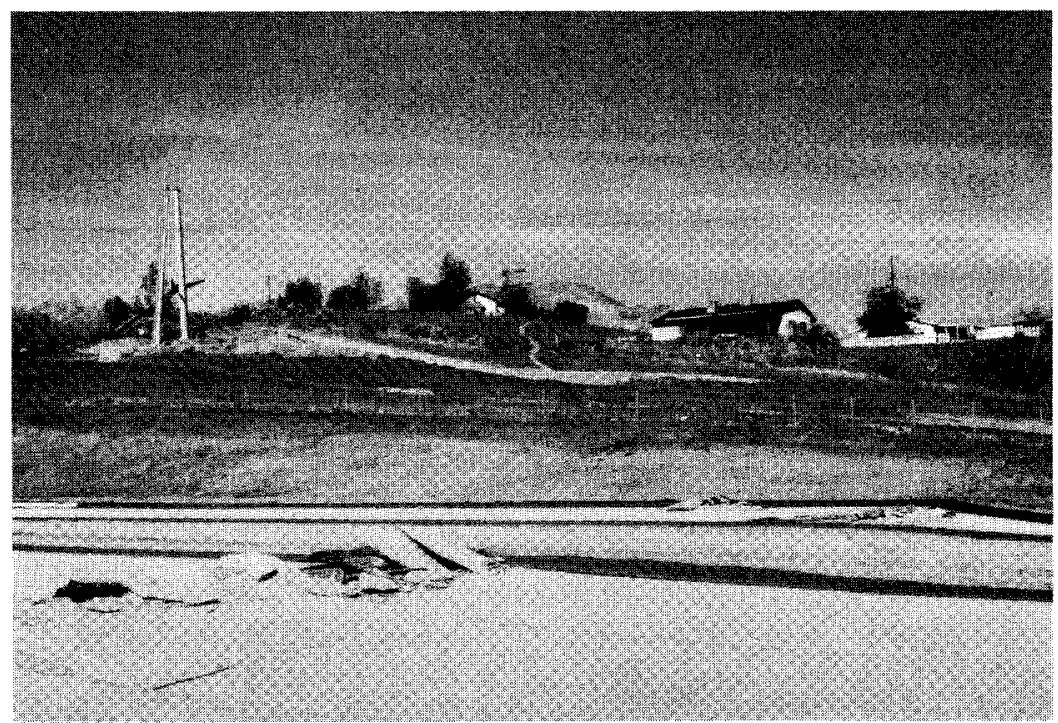

Figure 2. Damage to the 210 Freeway from fault rupture. Faulting caused extensive damage to underground utilities and structures along its surface traces. The transmission tower in the left background was under construction and failed at an uncompleted joint. 


\section{SIGNIFICANCE OF PERMANENT GROUND DISPLACEMENT}

The panel stated that "disruptions of the ground surface by faulting and other closely associated permanent deformations of rock and soil were much more important causes of structural failure during this earthquake than in any previous United States earthquake." They went on to note that the faults that broke were not generally shown on geologic maps and had not been considered particularly active. The panel then called for geological, geophysical, and geodetic studies to guide land use planning.

In one sense we took this lesson to heart and have made very significant progress. For example, paleoseismic studies have helped delineate the degree of hazard of many recognized faults, and this knowledge guides construction and development near the fault.

The bad news is that the situation seems significantly more complicated than we thought in 1971. The Whittier, Coalinga, Sierra Madre, and Northridge earthquakes all occurred on faults that did not break the surface of the ground, and even Loma Prieta showed distributed ground fissures over a wide zone, rather than breaking the ground surface on the main trace of the San Andreas fault.

\section{MEASUREMENT OF STRONG GROUND SHAKING}

The panel recognized the great value of the strong motion records obtained on buildings and dams, and in the free field. They deemed the present coverage inadequate and called for an expansion of the strong motion measurement efforts.

This lesson has endured. We, the political process, got the message and established the very effective Strong Motion Instrumentation Program of the California Division of Mines and Geology. The USGS program also improved, although much less dramatically. Recently, it has received another shot in the arm from the Northridge earthquake, so there is some ground for hope, although the USGS seems to be under special financial pressure and their program has recently lost personnel

\section{SIGNIFICANCE OF THE STRIKING LOCAL GROUND MOTIONS}

The panel cited the very strong shaking in the northern part of the San Fernando valley, noting that structures there were called upon to withstand both severe shaking and a heave upward and toward the south. They called particular attention to the record obtained at Pacoima dam, which showed both very strong shaking and a large displacement pulse.

I do not think even the earthquake professionals really learned this lesson in San Fernando, even though everyone was aware of the Pacoima dam record and the large pulse in the motion. The Pacoima dam record was generally studied from the viewpoint of attributing its high amplitude to effects of topography, location with respect to the surface rupture, etc. It took later records from Tobas, Iran in 1978, from the Imperial valley in 1979, but most dramatically from the Landers, Northridge, and Kobe earthquakes, to convince people that in the very near field, such strong shaking and pulses were more likely to be the rule than the exception. 


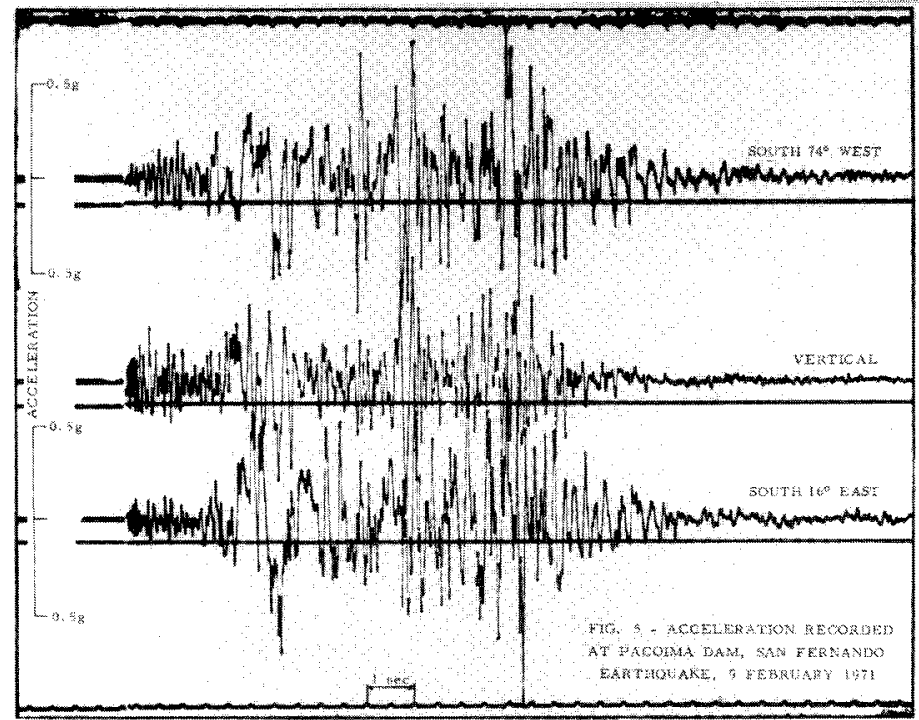

Figure 3. The original Pacoima Dam accelerogram (notes added). The large pulse in the motion begins about three seconds after the instrument was triggered.

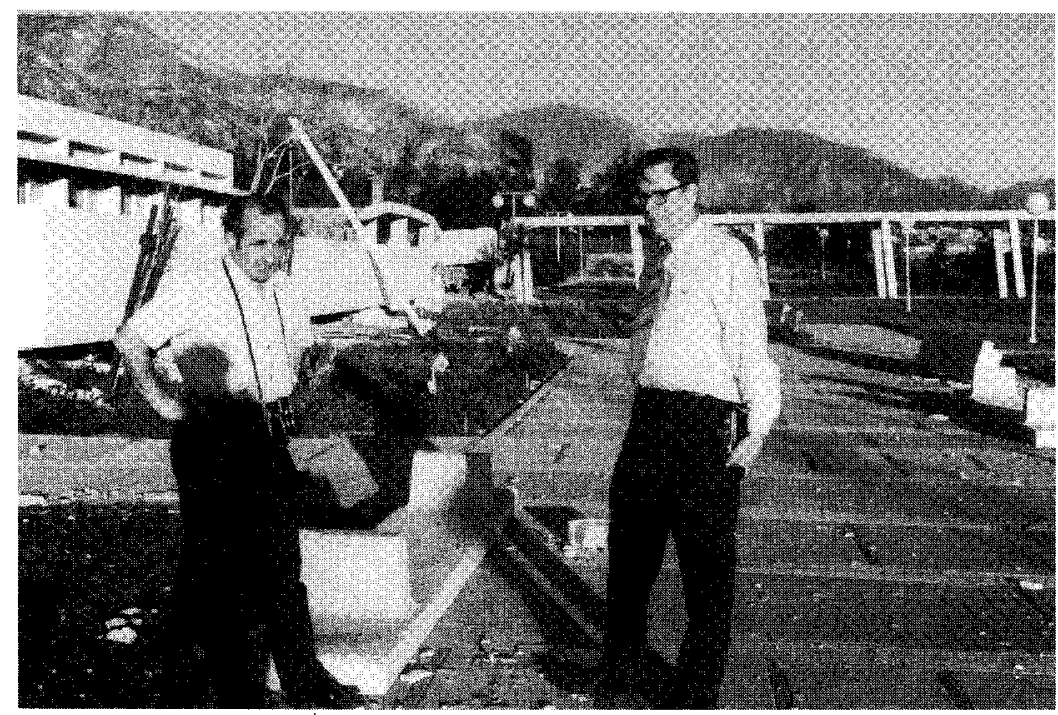

Figure 4. Overturned benches at the Olive View hospital provided indirect evidence of the very strong shaking experienced in the northern part of the San Fernando Valley. Professor George Housner is at the right and Professor Salu Sachanski from Bulgaria is on the left. The collapsed Psychiatric Day Care Center is in the left background. 


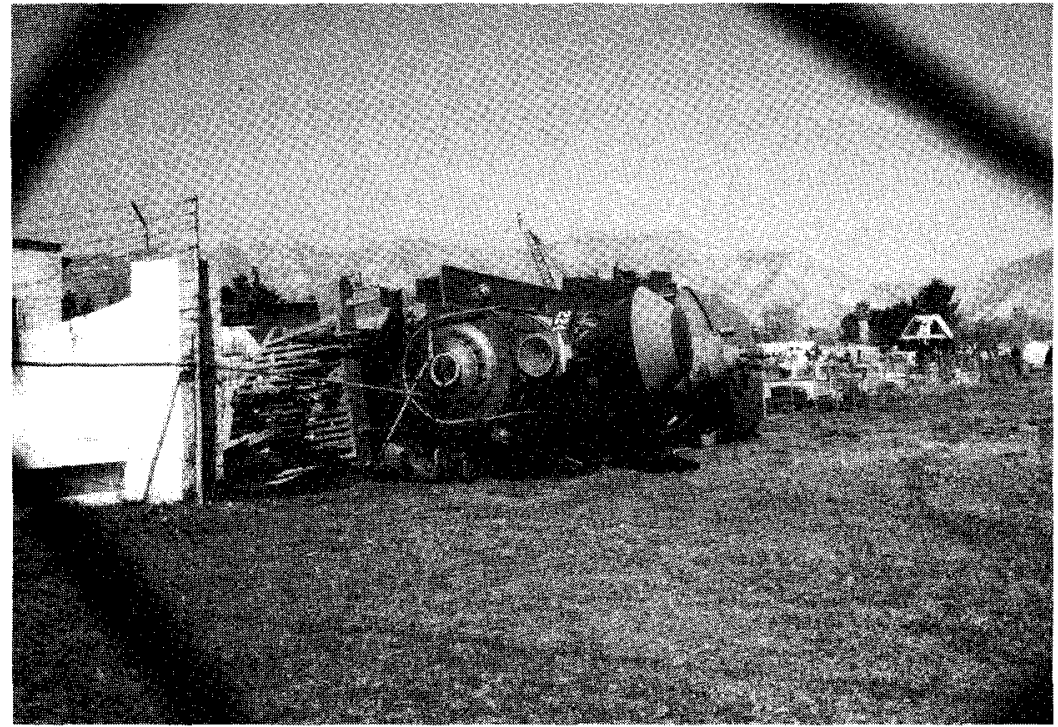

Figure 5. This overturned locomotive near Glenoaks Boulevard and Hubbard Street provides additional possible evidence of very strong shaking in the northern San Fernando valley, although flexibly-mounted structures can overturn under moderate shaking if conditions are right.

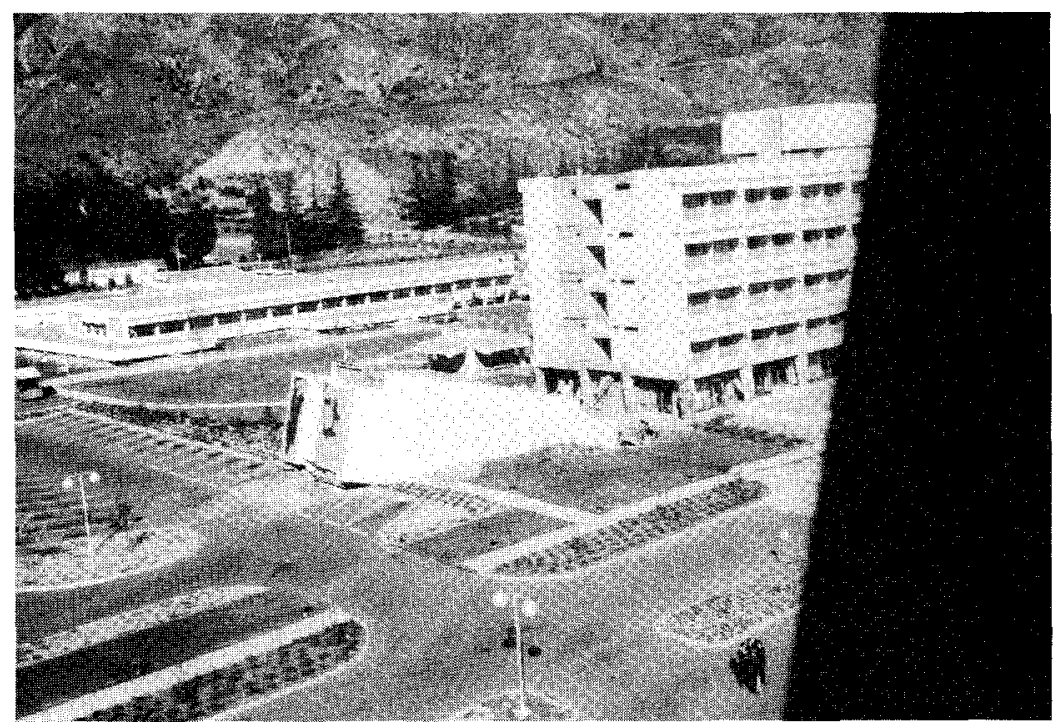

Figure 6. A portion of Olive View hospital as seen from a helicopter the afternoon of the earthquake. The stair tower in the foreground fell into the basement. The first floor of the two story Psychiatric Day Care Center collapsed in such a way as to leave the second story virtually intact. 


\section{BUILDING CODE REVISION}

The panel concluded that modern structures performed well in areas of moderately strong ground shaking (which they defined as 10 to $20 \% \mathrm{~g}$ ), but stated that some modern buildings collapsed in the area of strongest shaking and that other severely damaged structures would almost certainly have collapsed if the shaking had been of a longer duration. They concluded that "existing building codes do not provide adequate damage-control features. Such codes should be revised."

This lesson endured, but only in part. Some needed revisions in the codes were made rather quickly and an extensive effort led by the Applied Technology Council produced significant improvements later on. However, we lost the opportunity, since renewed by the Northridge and Kobe earthquakes, to develop building codes that considered the real, measured strength of strong shaking and structural response, and to include in the code design procedures directly aimed at limiting damage to structures (drift limitations do it indirectly), in addition to protecting the occupants from undue hazard. The development of performancebased earthquake-resistant design procedures is now being advocated by some leading engineers as a way to address directly the limitation of earthquake damage.

\section{BACK-UP EMERGENCY SERVICES}

The report states that police, fire, and medical services will be put under heavy stress following an earthquake of significant size, pointing out that the San Fernando earthquake was only a moderate event. The panel recommended a careful examination of emergency services to determine what back-up services are needed in preparation for a much larger earthquake.

I think this lesson was only partly learned; some needed changes were made, studies were done and plans and preparations assembled, but high-quality efforts were not universal.

\section{RAPID RECONNAISSANCE STUDIES}

The panel called for rapid reconnaissance studies, citing in particular the need for the pre-arranged assignment of rapid and systematic aerial photography of the affected areas to a specific organization.

The lesson of the potential value of aerial photography has endured. The Office of Emergency Services can, with the special approval of the Governor, commission aerial photography after a destructive earthquake. (Aerial reconnaissance was flown after the Northridge earthquake, but not by OES.) In the related area of rapid building inspection, OES organized after the San Fernando earthquake a coordinated system of trained volunteers and personnel who can be loaned from unaffected building departments. These engineers, in effect, augment the staff of the affected building department to speed the inspection of damaged buildings. 


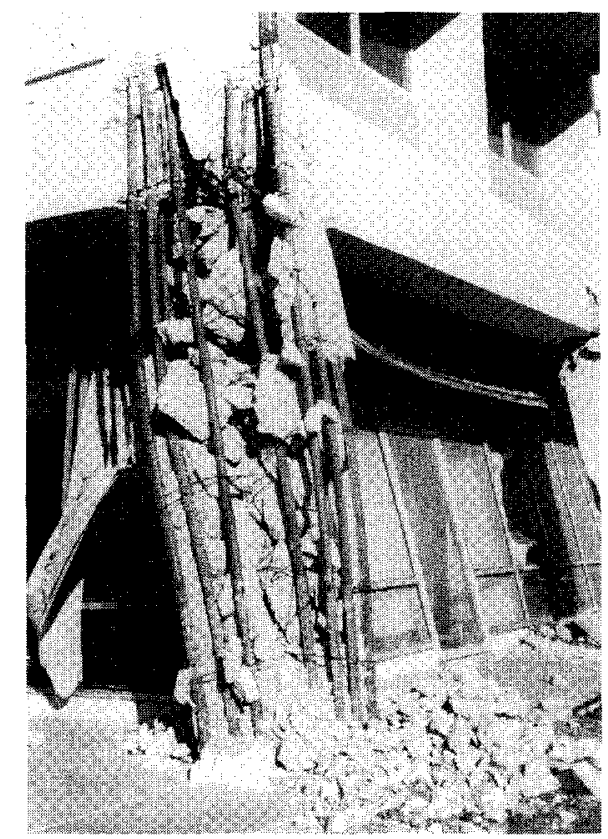

Figure 7. A first story corner column of the main building of Olive View hospital. The dramatic failure of columns with such light horizontal ties, \#3's ( $3 / 8$ in. dia.) at 18 in., provided convincing arguments for changes in the building code.

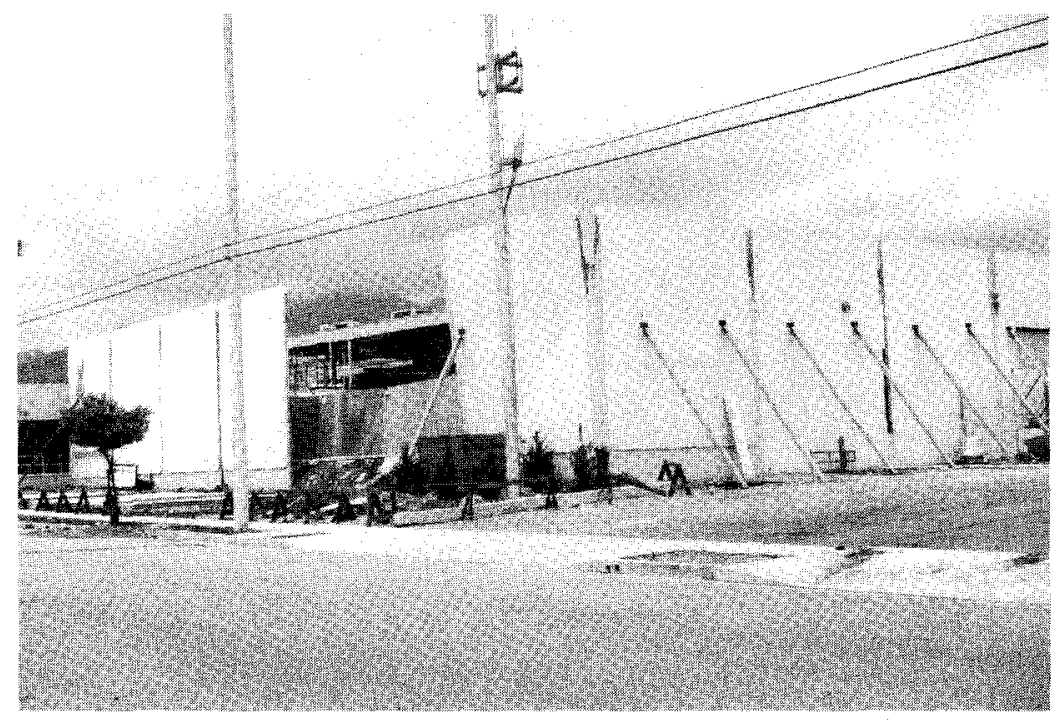

Figure 8. Failures in tilt-up construction were a common feature in the San Fernando earthquake. Significant improvements in the applicable codes were made afterwards, but failures of tilt-ups in the Northridge earthquake showed that additional improvements were needed. 


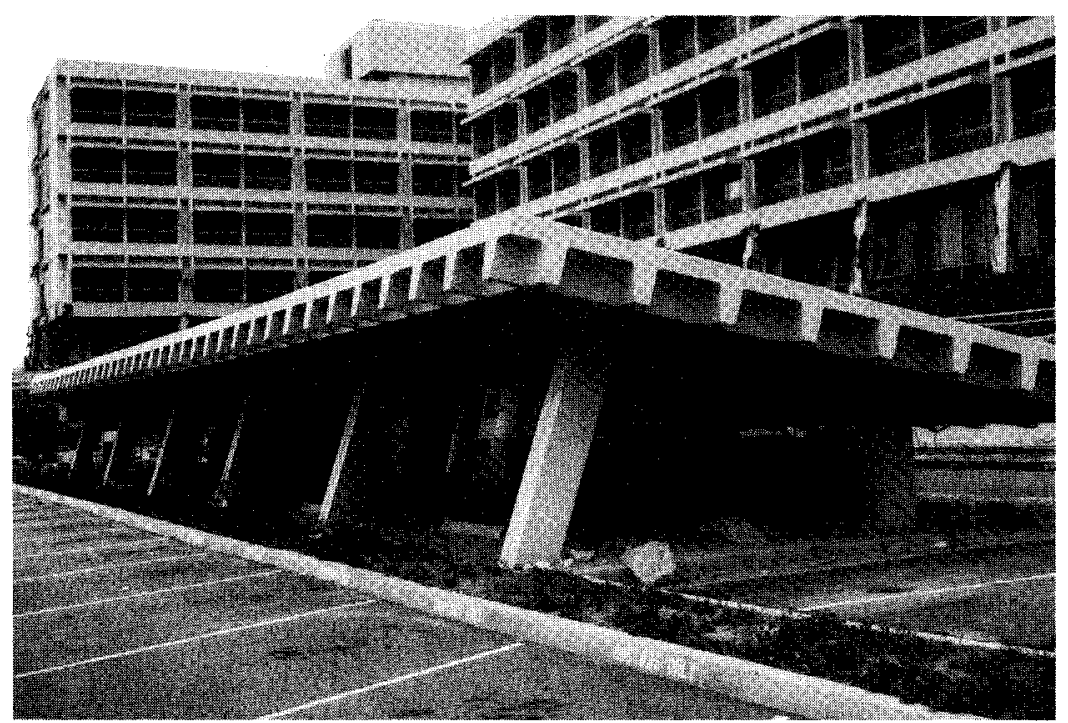

Figure 9. The collapsed pergola at the Olive View hospital destroyed the hospital's emergency vehicles. The stresses on the emergency services from the moderate-sized San Fernando earthquake pointed to the need for back-up facilities and careful planning in the event of a larger shock.

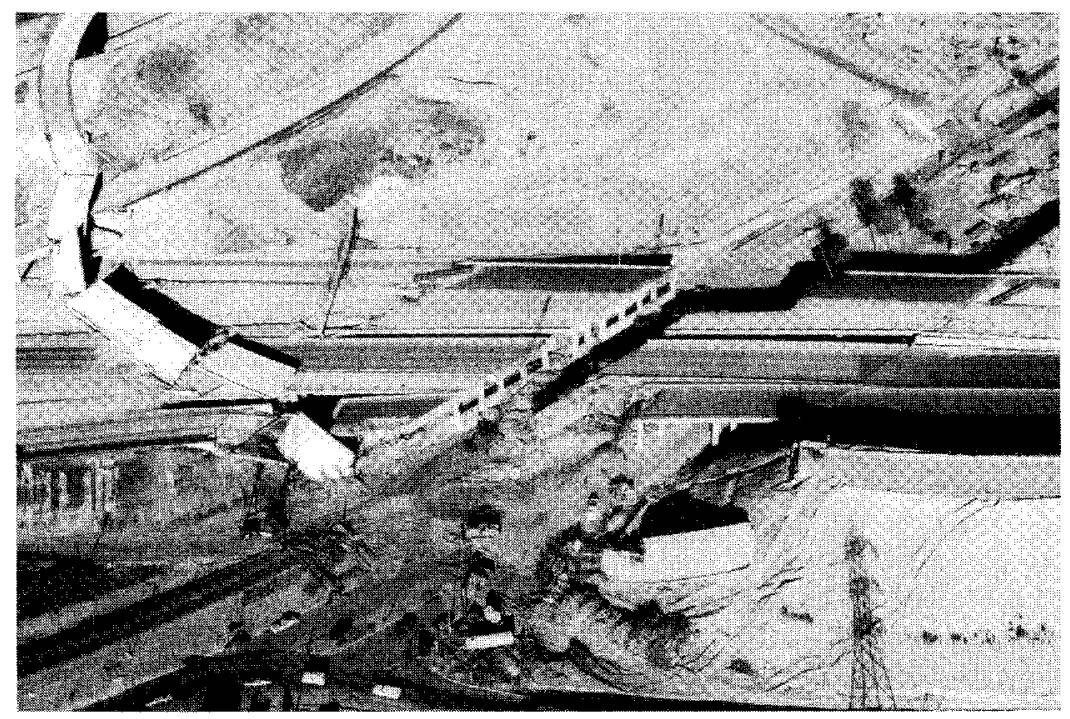

Figure 10. Aerial view of the 5-210 freeway interchange a few days after the San Fernando earthquake. Aerial reconnaissance and photography proved very useful in the earthquake, particularly in the early hours afterward when there was confusion about the damaged hospitals and freeway structures. 


\section{PROTECTION OF CRITICAL PUBLIC BUILDINGS}

The San Fernando earthquake left four hospitals in the area with serious damage or partial collapse, just when they were needed most. The panel called for changes in the codes so that critical structures, including hospitals, schools, and high-occupancy buildings would be designed to remain functional "even after experiencing the most severe ground motion."

This lesson was heeded, although one could argue now that 've did not appreciate the depth of the lesson. After San Fernando, hospitals were, in effect, included under the Field Act and an importance factor of 1.5, applicable to high-occupancy structures, was introduced into the building code. Many other changes were made in practice to increase the earthquake resistance of critical structures and facilities. The question posed by the Loma Prieta, Landers, Northridge, and Kobe earthquakes is whether these measures still fall significantly short of what is needed.

\section{EARTHQUAKE SAFETY OF DAMS}

The near collapse of the Van Norman dam led the panel to label as imperative an improved program to bring old dams up to the best modern safety standards. They also noted that basic research into the behavior of dams and soil structures would be required for the implementation of such a program.

This is one of the lessons that was taken to heart. The program of the State Division of Dam Safety has worked steadily and successfully over the years to increase the earthquake safety of dams. I believe nearly all of the hazardous dams have either been strengthened, or have been replaced by new ones (local examples near Los Angeles include Big Bear, Lake Arrowhead, and Littlerock dams).

Since 1971, basic research has helped clarify the complicated dynamics of the earthquake response of dams. However, much remains poorly understood, particularly for earth dams, where it is hard to demonstrate a clear relationship between the earthquake forces used in the design and the capacity of the structures to resist much stronger shaking.

\section{EARTHQUAKE HAZARD OF OLD STRUCTURES}

The major loss of life in the San Fernando earthquake came from the collapse of an old building at the Veteran's Hospital in Sylmar. Many other old buildings showed severe damage. The panel strongly recommended much more extensive programs than then existed to reduce the major hazard posed by old buildings.

In this case, the Veteran's Administration got the message, as did the city of Los Angeles and some other cities. The VA rather quickly strengthened or rebuilt its hospitals in seismic areas; the progress in L.A. was slower, but an ordinance was eventually enacted, and well over half of an estimated 8000 old unreinforced masonry bıildings have been either retrofitted or taken out of service.

Many other cities have not faced the problem of their old buildings, even though it is one of the most obvious and enduring lessons that can be learned from earthquakes. 


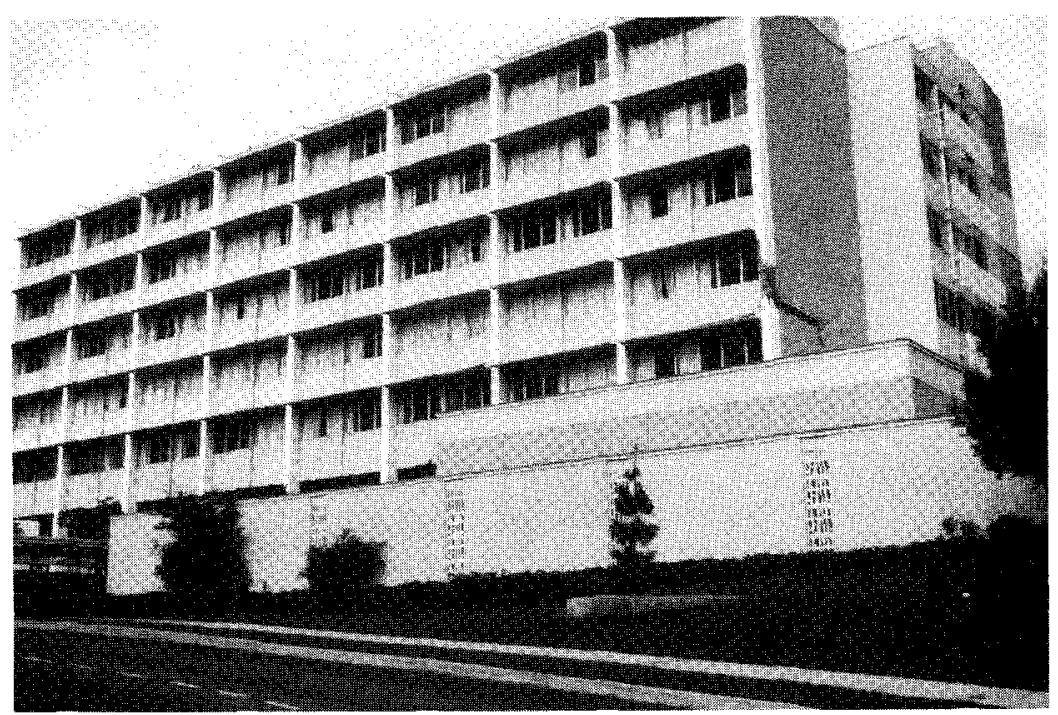

Figure 11. Holy Cross hospital was one of four hospitals that were very heavily damaged during the San Fernando earthquake and were unusable at a time when they were most needed. This experience led to special considerations for the design of hospitals, similar to the Field Act for schools.

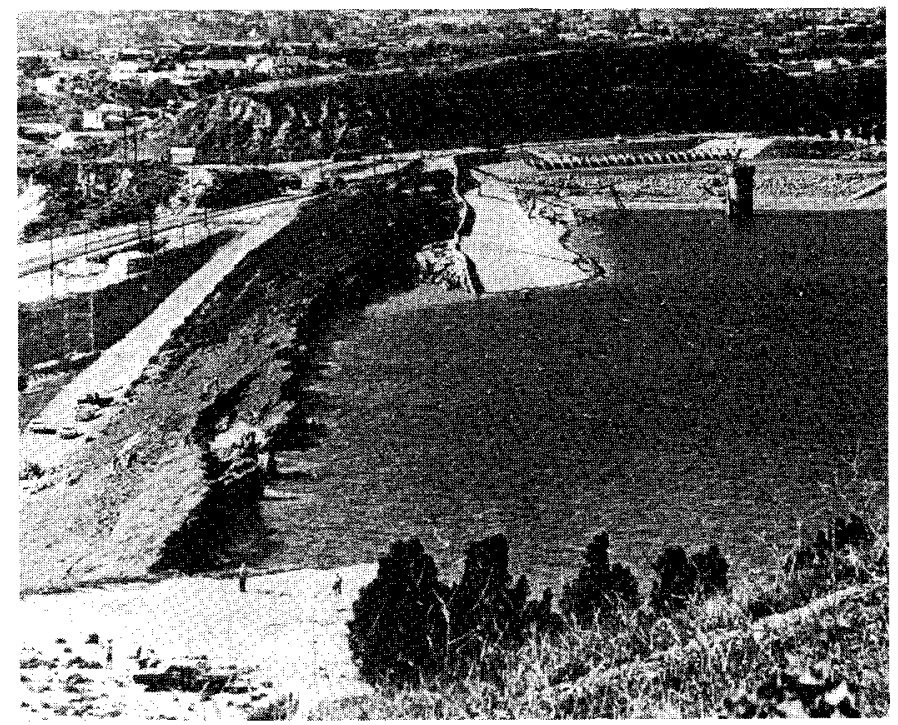

Figure 12. Lower San Fernando dam on the day of the earthquake, looking west. The crest of the dam, a second outlet tower and the concrete erosion apron all slid into the reservoir. The reservoir surface was within a few feet of the top of the escarpment at this time, but the remaining part of the dam held and the water level was safely lowered. 


\section{SAFETY OF BRIDGES AND FREEWAY OVERPASSES}

The San Fernando earthquake was the first to show the vulnerability of modern freeway structures to strong shaking. The collapse and damage were spectacular and showed the structures to have serious deficiencies, particularly in the shear reinforcement of columns and in the amount of support provided for spans at joints.

This lesson was heeded by Caltrans, which quickly adopted interim design changes, followed later by fundamental revisions in their procedures for design. The public and the political leadership did not learn the lesson well, however, and Caltrans and other agencies did not receive enough financial support for their efforts to strengthen ıapidly the bridges of the state. Spectacular bridge collapses and damages from the Loma Preita earthquake were needed to accelerate the retrofit program, but progress, again limited primarily by funding, was not rapid enough to prevent collapse or serious damage to several unretrofitted bridges in the Northridge earthquake. Northridge has, in turn, prompted efforts to increase the financial support of retrofit programs.

\section{SAFENESS (SIC) OF SCHOOL BUILDINGS}

The panel pointed out that Field Act schools in the area of strong shaking did not suffer hazardous structural damage, while older school buildings which did not meet the Field Act did experience potentially hazardous damage (schools were not in session). "The lesson is clear that such hazardous school buildings must be eliminated or strengthened." Surprising as it might seem now, the Field Act was viewed as overkill in some quarters prior to the San Fernando earthquake and was under attack.

The San Fernando earthquake did cause some non-structural damage to school buildings in the form of partially fallen light fixtures, damaged ceiling tiles, etc., but the higher degree of hazard from non-structural damage seen in schools in the Northridge earthquake was not evident in 1971 .

\section{STUDY OF DAMAGED URBAN DWELLINGS}

The report cited the extensive damage to small homes and small-business structures in areas subject to strong shaking and permanent ground deformation. It called for a dwelling by dwelling study of the damage, "...With a view toward developing sounder guidelines for building construction, particularly for one-and two- story buildings."

This lesson endured in a limited sense. For example, after the San Fernando earthquake many more individual homeowners voluntarily had the foundations of older homes inspected-and bolted and braced, if necessary--a practice accelerated still further by the more recent earthquakes. However, we did not learn the true level of hazard posed by multi-unit apartments where they had a weak first story, or where other systematic weaknesses in design or construction were present. If anything, the generally successful performance of wellconstructed single and multiple-unit wood-frame housing away from areas of ground rupture seems to have encouraged an unjustified sense of security. The Northridge earthquake showed us that there are more poorly built structures of these types than we then thought. 


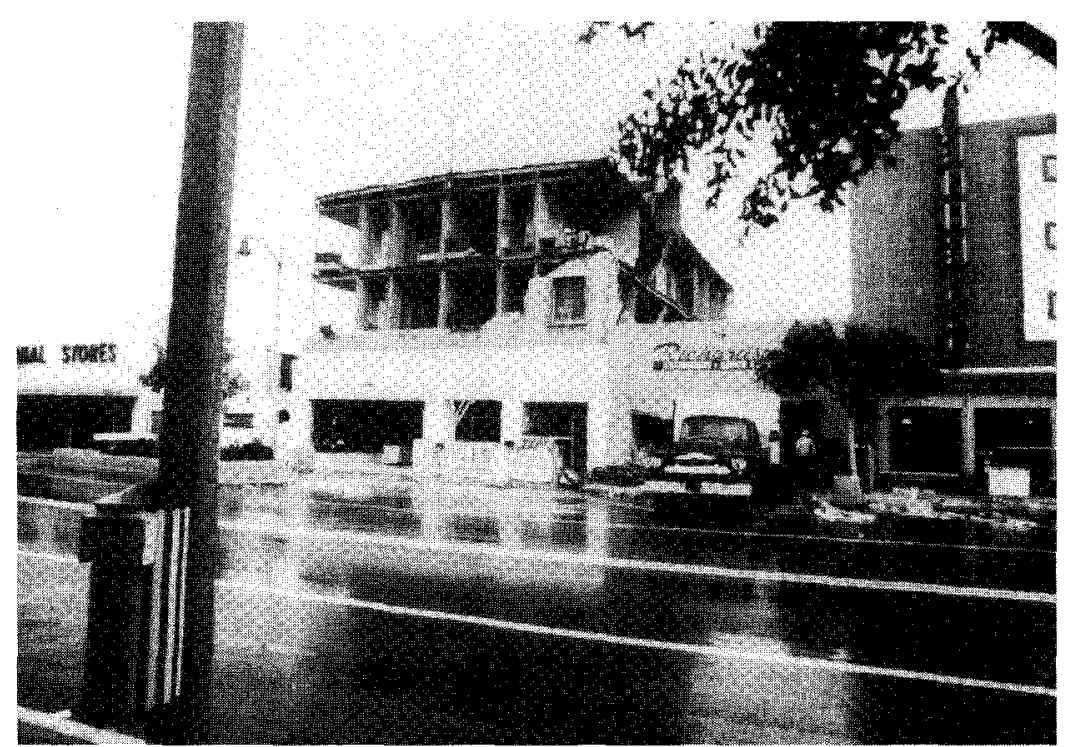

Figure 13. Failure of old buildings was an expectable feature of the San Fernando earthquake, accounting for nearly all of the casualties. This old brick building in downtown San Fernando showed the classic loss of exterior walls, while the partitions held up the remaining structure. Any occupants of the upper story bedrooms must have had an unforgettable experience.

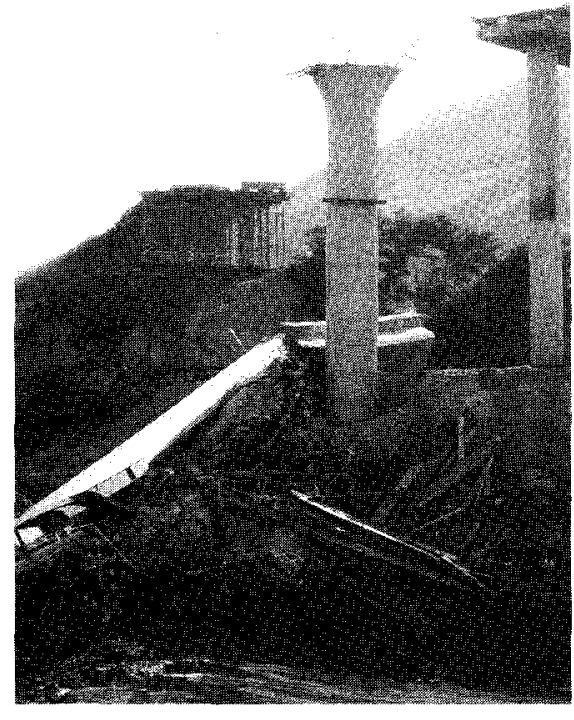

Figure 14. The San Fernando earthquake was the first to show the vulnerability of some modern freeway structures to very strong shaking. This figure shows damage to the 5-14 freeway interchange, which was under construction at the time. The overpass structure on the ground came off its seat near the pillar on the right and slightly damaged the closer pillar during its fall. 


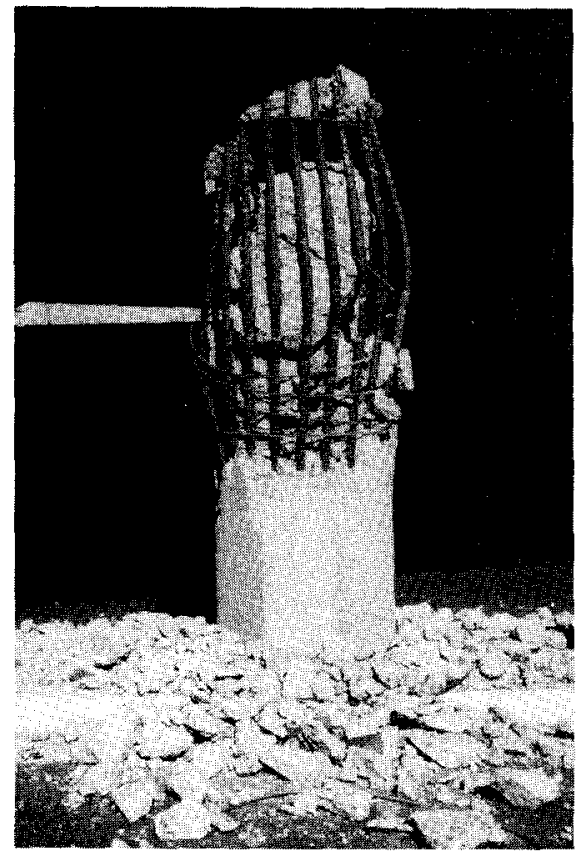

Figure 15. One of the failed columns supporting the Foothill Boulevard undercrossing of the 210 freeway, near Olive View hospital. The column failed in shear because of inadequate horizontal ties.

The vertical reinforcing bars were \#18's ( $2-1 / 4$ in. dia.), while the lateral ties were \#4's (1/2 in. dia.) at 12 in. spacing. The unacceptable performance of bridge and freeway structures in the San Fernando earthquake quickly led to changes in design practices.

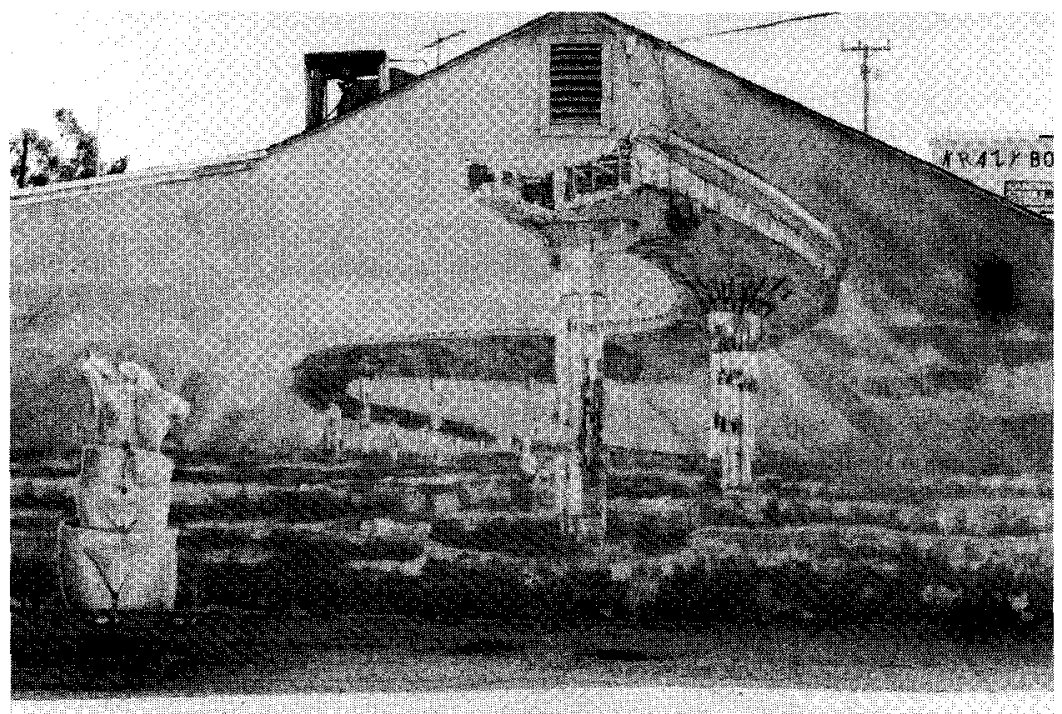

Figure 16. The spectacular failure of some freeway structures in the earthquake inspired this mural on a building in Los Angeles. The damage to freeway structures seen in the San Fernando, Loma Prieta, Northridge and Kobe earthquakes was so dramatic that images of such damage have become a kind of symbol of the risk of living in earthquake country. 


\section{EARTHQUAKE INSURANCE FOR HOUSES AND SMALL BUSINESSES}

Using the fact that homeowners had no real way of knowing the full nature of their earthquake hazard, which in some cases included ground deformation, landslides, and slumping in addition to the expectable strong shaking, the panel called for the creation of earthquake insurance that could be widely used.

We seem to learning this lesson on a geologic time scale. Experience in the San Fernando earthquake helped spur interest in earthquake insurance, but even with the added impetus of at least six more damaging earthquakes (Whittier, Sierra Madre, Coalinga, Imperial Valley, Loma Prieta, Northridge), we are still struggling to find a balance among the financial, political, and technical forces that impact earthquake insurance.

\section{PRESERVATION OF VITAL SUPPORT SYSTEMS}

The San Fernando earthquake clearly showed the increasing vulnerability of our vital support systems to damage in major earthquakes. Citing the extensive damage to the Sylmar Converter station and the Van Norman dam as examples, the report stated that it is inadequate to consider only the individual components and called for the construction of redundant systems.

In this case we may have learned the lesson, but have not solved the problem, although very significant progress has been made. The earthquake resistance of urban support systems has received a lot of attention in the intervening years. They are now called "lifelines", or "infrastructure". Both the general public and the organizations that operate the systems are more aware of earthquake hazards to lifelines, and advances made in practice and research have contributed to increased earthquake safety. Nonetheless, it is hard to anticipate all the effects of earthquakes on these systems and it seems prohibitively costly to provide direct protection against such effects as widespread ground deformation and overloading of communication capacities.

\section{THE PROBLEM OF SEISMIC ZONING}

The panel first concluded that "No evidence from previously completed geological or seismological studies had been generally interpreted as indicating the region affected was a more likely place for a damaging earthquake than many other parts of the southern California seismic region." They then went on to recommended that until we understand the earthquake process better, seismic hazard should be considered high over wide areas, and seismic zoning maps should reflect this.

This lesson has endured, unevenly perhaps, as overly precise estimates of seismic hazard and risk still seem plentiful. However, major consensus studies like the recent Southern California Earthquake Center's Report, Seismic Hazards In Southern California: Probable Earthquakes, 1994-2024 (Bulletin of the Seismological Society of America, Vol. 85, No. 2, pp. 379-439, April 1995), show very broad zones of equal probability of hazardous shaking on rock sites. 


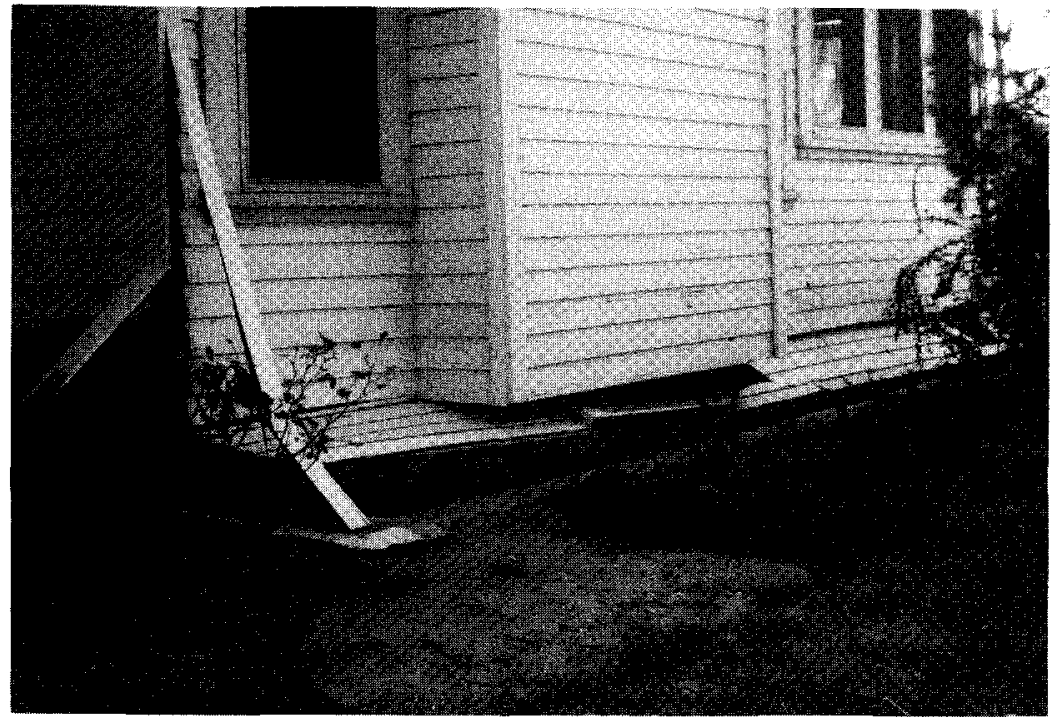

Figure 17. Failure of older wooden homes on unbraced foundations was evident in the San Fernando earthquake, and continues to be a common, preventable feature of California earthquakes in the areas of strong shaking.

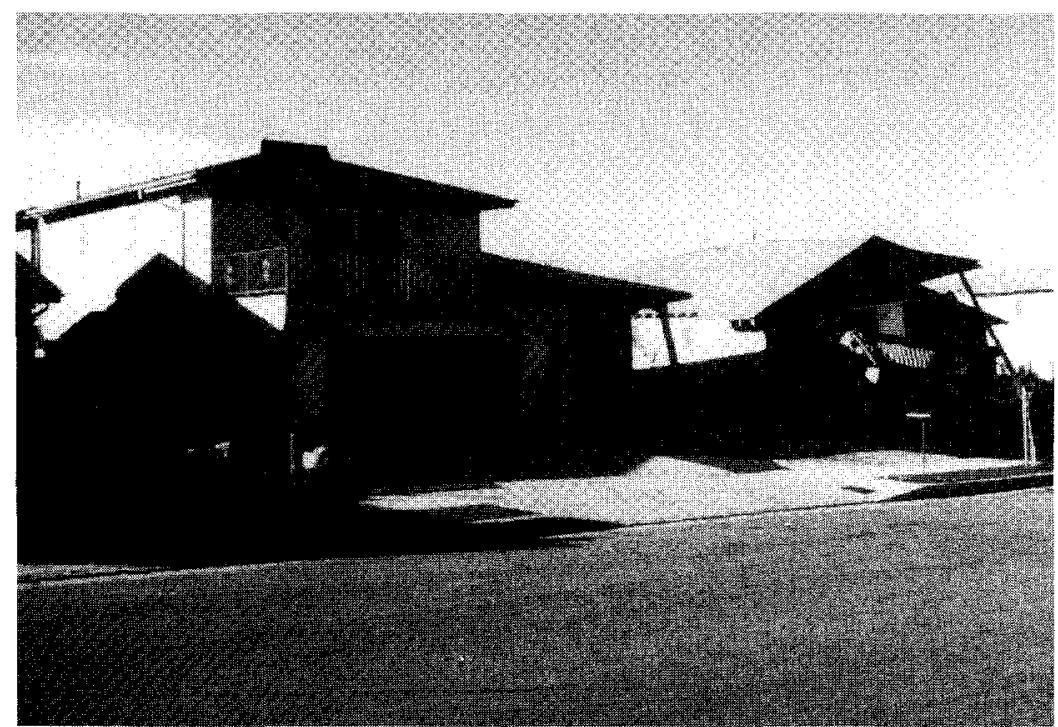

Figure 18. Some failures to new wood frame housing also occurred in this earthquake, primarily because of defects in construction and lack of sufficient shear strength in two-story structures. These two features later were major causes of the much more extensive damage to wood frame structures in the Northridge earthquake. 
The recent earthquakes on buried faults demonstrated that gauging and mapping the intensity of expected shaking by the distance from known faults is severely limited by lack of knowledge of the existence, location, and degree of activity of major earthquake sources. The lesson stated after the San Fernando earthquake has only been reinforced by subsequent experience.

\section{LAND USE AND GEOLOGIC HAZARDS}

The San Fernando earthquake caused extensive damage by faulting and permanent ground deformation, and was accompanied by many landslides in the mountains. The panel concluded that permits for construction in areas subject to earthquakes and other environmental hazards should be issued only on the basis of a meaningful evaluation of the risks. State and local governments were seen to need well-conceived regulations if they were to resist political and economic pressures for unwise land development.

This lesson was not lost on earthquake professionals and the San Fernando earthquake did provide more evidence for efforts to reduce the risks posed by land development in hazardous areas. These efforts seem to have some beneficial effects in practice. For example, some influential hazard maps and scenarios have been produced. However, appropriate land use is a very complex issue, and it is not so much a problem to be solved as it is a continuing, dynamic process.

\section{STUDY OF THE SOUTHERN SECTOR OF THE SAN ANDREAS FAULT}

The panel stated that the San Fernando earthquake had to have had some effects on the nearby portions of the San Andreas fault and noted that this "locked" section of the fault was particularly important because of its proximity to the Los Angeles urban area. They called for additional research at once to study the southern part of the San Andreas fault.

I attribute part of the urgency of this recommendation to the fact that the panel met on February 25-27, 1971, less than three weeks after the earthquake. At that time it would not have been surprising had the San Fernando earthquake turned out to be only a foreshock of an even bigger event on the lower San Andreas fault. Fortunately, that did not prove to be the case, but in the weeks following the San Fernando earthquake one could hardly experience an aftershock without wondering if it were the San Andreas letting go.

I think this lesson of the need for study of the San Andreas fault was heeded. Kerry Seih's landmark study of prehistoric large earthquakes on the fault at Pallett creek appeared in 1978. Since that time, not only have other portions of the San Andreas fault been studied extensively, but many other faults have been studied by trenching and other means to determine the times of prehistoric earthquakes and to estimate their geologic slip rates for the purpose of defining earthquake hazard. In at least a fuzzy sense the general public has become aware of the hazard from the San Andreas fault, evidenced by the addition of the phrase "the big one" to the local idiom. 


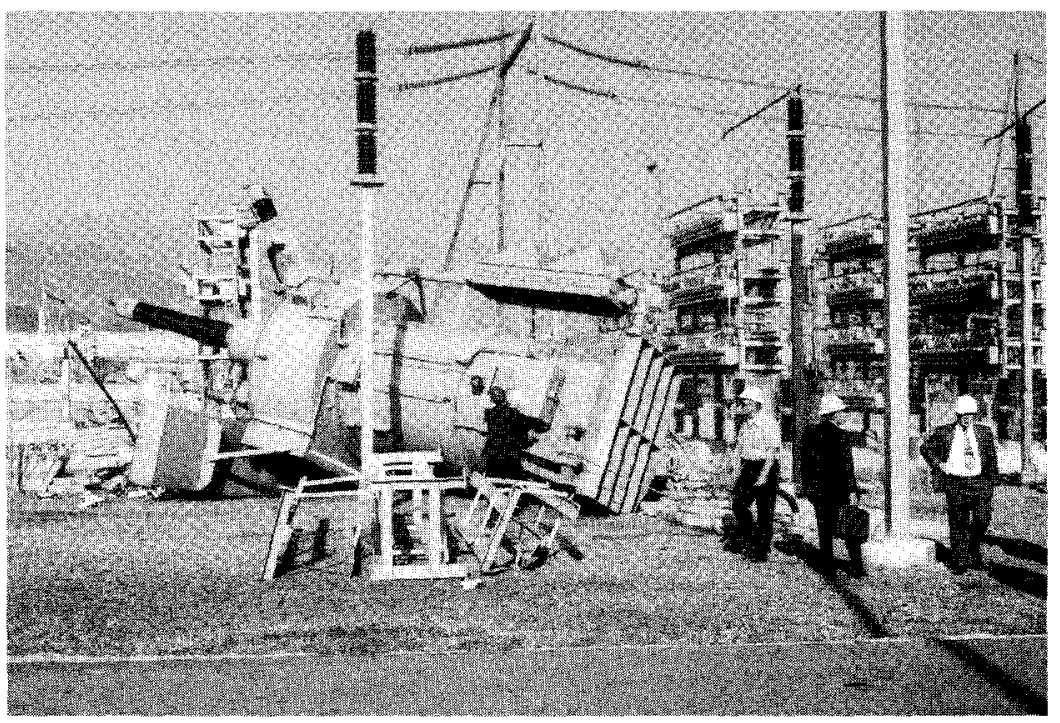

Figure 19. Extensive damage to equipment at the Sylmar Converter station during the San Fernando earthquake was very costly (an estimated $\$ 28$ million. loss in 1971 dollars) as well as disruptive to the restoration of normal electric power services.

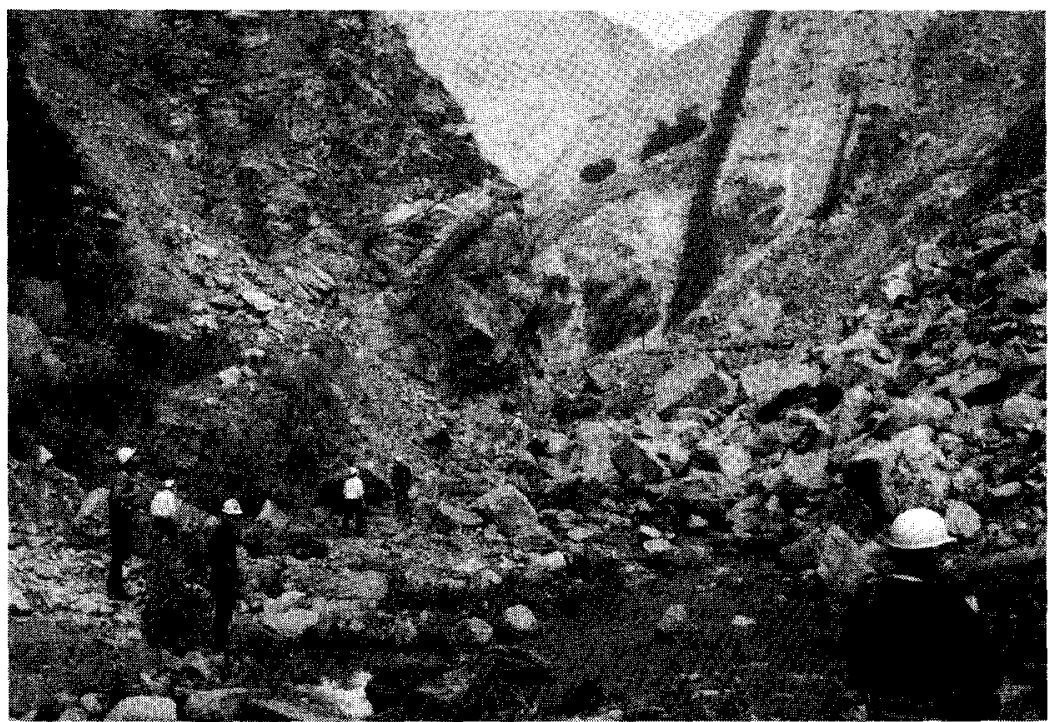

Figure 20. Landslides were very common in the nearby mountains during the main shock and continued to a lesser degree during the larger aftershocks. This photograph shows a party cautiously working its way up Pacoima canyon to the accelerograph site a few days after the San Fernando earthquake. 


\section{SEISMOLOGICAL STUDIES}

In its final lesson, the panel noted the value of the telemetry-equipped seismographic network to both the scientific understanding of earthquakes and to the delineation of the scope of the disaster. Although GPS was not yet on the scene, the panel was well aware of the value of geodetic information in the study of earthquakes. They called urgently for upgrading of the seismological and geodetic capabilities in all the earthquake-prone parts of the country.

This lesson was largely ignored, particularly the aspect of urgency. Some networks have improved significantly since then, but the process has been incremental. San Fernando and other recent earthquakes occasionally help spring loose some resources or start new programs, as has happened again after Northridge, but the basic maintenance and upgrading of the seismological networks seems to remain a problem. I recall meetings with the USGS in the late seventies or early eighties where we discussed how to reduce programmatic costs so they would have funds to buy photographic paper for seismographs.

\section{ADDITIONAL LESSONS}

As mentioned above, there were many extensive studies and reports written about the effects of the San Fernando earthquake. The reports drew conclusions, of course, but they tended to be specific to the details of the individual studies. Where general "lessons" were stated they generally were similar to those of the NAS/NAE/NRC panel. This is not surprising, as the panel comprised a broadly knowledgeable and experienced group.

There are a few additional, general lessons that I found in my review of some of the reports of the earthquake. The first that I should mention concerns non-structural damage. A number of reports documented the extensive damage to ceilings and light fixtures, to machinery, to elevators, to sprinkler systems, and to equipment in general. The lesson here was that these components of modern buildings can be very vulnerable to strong shaking and unless something is done to prevent or control the damage, their failure can be very costly and quite hazardous to the occupants.

Only a part of this lesson was learned. I recall significant efforts to improve the safety of elevators after the San Fernando earthquake, and improvements were made in the codes and practices for the design of equipment mountings. Recent earthquakes, particularly Northridge, have shown that much progress is still needed in this area.

I want to bring to the attention of the reader one other lesson that I found while looking over some of the many volumes written about the earthquake. This lesson is one which went unheeded and poorly understood at the time, but came back in full force in the Northridge earthquake. It comes from a report written for HUD by former EERI President, Frank McClure: Performance Of Single Family Dwellings in The San Fernando Earthquake of February 9, 1971. It was published in 1973. In this report, McClure pointed out that the total dollar losses to single family dwellings in the earthquake were larger than the dollar losses to any other building category in the private sector, and of even more significance, I believe, that these losses were much greater than reported in damage surveys made immediately after the 
earthquake by local governments. The principal cause of the damage was inadequate structural bracing.

This unheeded lesson holds equally well for much multi-unit housing construction. Engineers familiar with practices of housing construction over the past two decades have informed the writer that deficiencies in design and construction are both widespread and serious. This situation gives warning of large future earthquake losses from damage to housing construction.

When combined with the widespread purchase of residential earthquake insurance in the decades following the San Fernando earthquake, and the famous words of repair work "while we are at it", this lesson also provides a background for understanding in hindsight the many billions of dollars of insured losses experienced in the Northridge earthquake.

\section{CONCLUSIONS}

The San Fernando earthquake of 1971 was a turning point in our recent seismicity, and in the public's awareness of seismic risk. It provided the first strong shaking experienced by the metropolitan Los Angeles area since the Kern County earthquake of 1952, with shaking much stronger in most areas than it was in the 1952 event. Things had also been pretty quite in the Bay area. The magnitude 5.3 San Francisco earthquake of March 22, 1957 and the 5.6 Santa Rosa earthquake of October 1, 1969 had given the Bay area its strongest shaking since 1906 (and continued to do so until the Loma Prieta earthquake). At the time of the San Fernando earthquake, a good fraction of the people in California, including those in positions of leadership and even those studying earthquakes and designing buildings and bridges, had never themselves experienced really strong shaking. It is not surprising then that earthquake preparedness and support of earthquake research were rather far down the list of political priorities.

In a broad sense, some of the lessons of San Fernando, repeated for emphasis in several more recent events, have made an impact. The general level of public awareness is significantly higher now than it was in 1971. Also, there is now actually a strong earthquake engineering industry: companies exist that make strong-motion instruments, that do dynamic testing, that evaluate hazards and risks, and provide equipment to isolate buildings and bridges from strong shaking. There are experienced contractors that can brace the foundations of older houses. We now can even buy earthquake survival kits and materials to fasten things down in the home. Finally, I can point out that the issue of earthquake insurance has moved from the back burner to the front of the stove.

There has also been very important scientific and engineering progress since 1971, advances I will not address but which could be the focus for a different review.

Summing up, the earthquakes in Loma Prieta, Landers, Northridge, and Kobe have shown us that there are many, many things remaining to be done, but we have, in fact, come quite a way since San Fernando. 